\title{
Evolution of the Rajang's Traditional Housing Typology in Kanowit, Sarawak
}

\author{
Salfarina Abdul Gapor*, Rahmat Moriat and Haris Fadzilah Abdul Rahman \\ Department of Architecture, \\ School of Built Environment, University College of Technology Sarawak \\ *Corresponding author: salfarina@ucts.edu.my
}

\begin{abstract}
Typology study involves typological analyses by categorizing buildings within the same class on the basis of their differences. The study of building typology is more related to similar functions but of different form. Form can be with regards to roof, site location, façade, building materials, ornaments, detailing, spatial programming and etc. Typology study is important for decision in policy-making related to conservation and promoting regional architectural characteristics. In academic points of view, typology study provides a fundamental basis to generate knowledge in architectural discourse, particularly in the understanding of the origin and evolution of vernacular architecture and the complex influences of culture, economic and the immediate environment to characteristics of the types of similar building, making the study relevant for historical references. This paper focuses on examining the different typology of the Rajang's traditional dwelling. The Rajang is part of the Melanau ethnic group in Sarawak. The mighty Rejang River was named from this sub ethnic group of the Melanau - the Rajang. There is also a close affinity between the Rajang and the Melanau of Kampung Nangka and Kampung Banyok Sibu, in terms of language and family kinship. The Rajang tangible culture, in particular, the traditional vernacular housing is facing threat of loss due to modernisation and assimilation with the mainstream group of Sarawak, such as with the Malays and Iban. Therefore, it is critical to document the traditional typology of the Rajang's vernacular housing. Thus, the objective of this article is to examine the evolution of Rajang's traditional housing typology from the sixteenth century up to the twentieth century. Findings show that, there are three main typology of the Rajang vernacular housing, namely - the Early typology; the Intermediate typology and the Modern typology. Findings also show that the characteristics of the Early and Intermediate typologies are similar in terms of scale and ergonomic requirements. The Early and Intermediate housing are based on traditional scaling based on human scale, known as the "depa", whereas the Modern typology are built based on British standards scale, using feet and later meter. Therefore, the Modern typology are larger and slightly taller. All typologies are minimalist with very little ornaments.
\end{abstract}

Keywords: Kanowit, Melanau, Rajang, Sarawak, Typology, Vernacular Housing

\section{Introduction}

The Melanau can be categorised according to their geographical location, those residing along the coastal areas and those inhabiting the inland along riverine villages. Majority of them are along coastal areas of Sarawak such as from Paloh, Bruit, Jerijeh, Belawai, Matu, Daro, Igan, Oya, Mukah, Dalat, Balingian and Bintulu. The Rajang is considered as the Melanau sub-ethnic who inhabit inland riverine villages, and in terms of language and culture there are closest to the Melanau of Kampung Nangka in Sibu and the 
Tanjong of Belaga. Other riverine Melanaus include the Tanjong, Kampung Nangka and Kampung Banyok Melanau. All including the Rajang resides along the Rajang River. The Rajang world belief has evolved like the rests of the Melanaus. Originally, they are animist or termed locally as Pagan. Now, many have converted to Christianity or Islam. However, they still retain their culture and traditional belief despite the conversion.

Kanowit is a small town located at the confluence of Kanowit and Rajang river under the administrative governance of Kanowit District, which is also under the Sibu Division in the state of Sarawak, Malaysia (Refer to Figure 1). In 2010, the population of Kanowit is 28, 954 (Department of Statistic Malaysia, 2010). The main ethnic groups in Kanowit are the Iban, Melanau (Rajang), Malay and Chinese. The origin of Kanowit, according to the locals, was based on an ethnic group, the Rajang's language. The Rajang is a subethnic of the Melanau group and their language is called Kanowit (Borneo Post, 2015). The Kanowit river is also named after the Rajang's language.

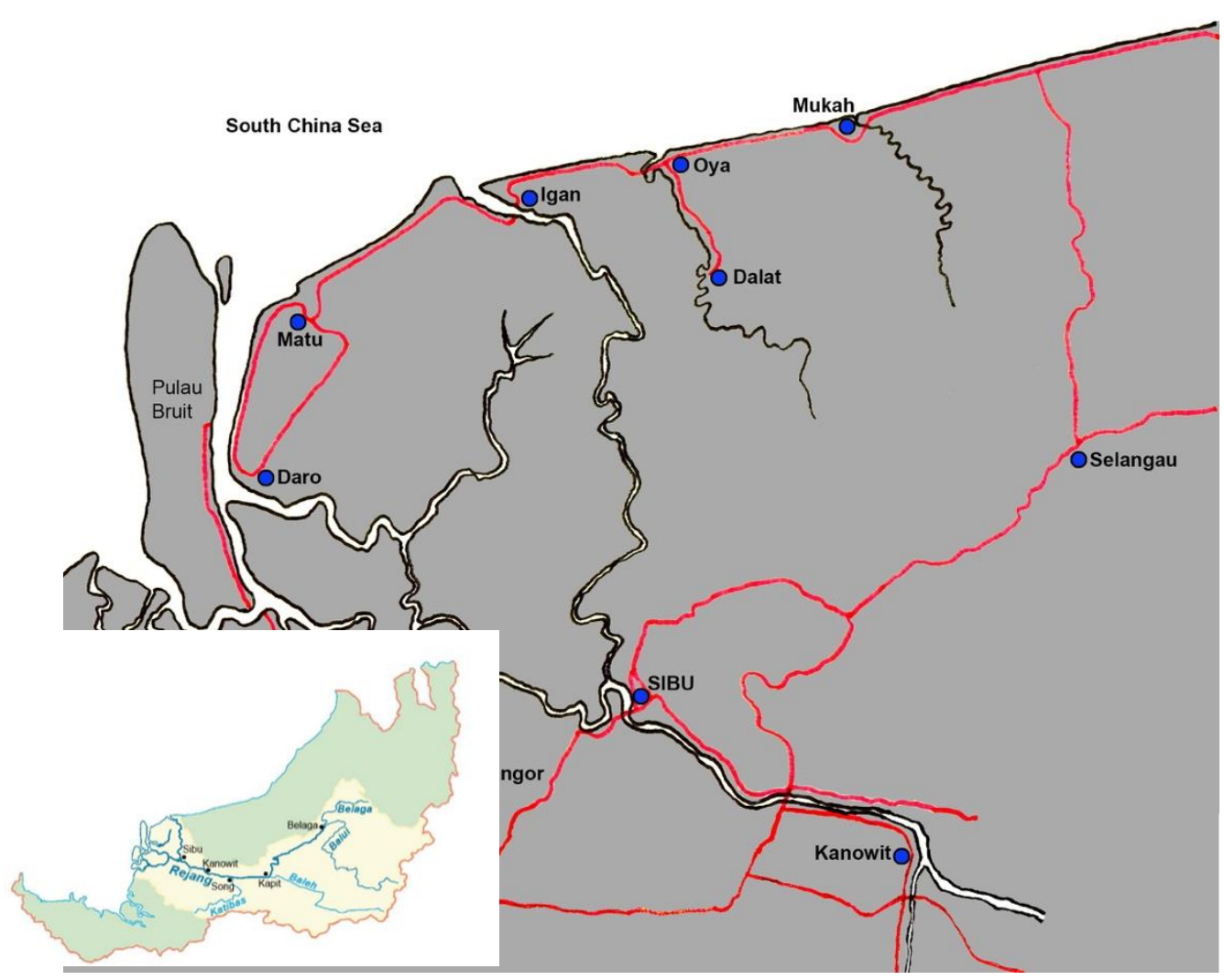

Figure 1: Map of Kanowit in relation to the Rajang Delta and Sarawak Source: Author

It was believed that the Rajang is the first ethnic group residing in Kanowit. Kanowit started to develop as a small town when Brooke expanded his territory to fight the pirates as invited by the Sultan of Brunei. Fort Emma was built in 1851 to fight against piracy in this area and Brooke took over Kanowit and the Rajang delta by 1853 from the Brunei Sultanate (Borneo Post, 2015). The most important event after Brooke set up his post at Kanowit was the killing of two Brooke Officers, Charles Fox and Henry Steele by two Rajang by the name of Sawing and Sakalai in 1859 (PeKhabar, 2015; Nor Hisham Osman, 1991; Kaboy, 1965). However, it was also believed that Sharif Mashor, the 
Melanau/Malay leader in this area had earlier attempted to kill Fox and Steele but had not been successful. Sawing and Sakalai later escaped downstream Rajang River to the Kejaman and Kayan areas. However, later Sawing was caught and faced death penalty in Kuching in 1863.

Kanowit was later developed as a trading town that supplied agricultural and jungle products to Sibu when the Cantonese arrived in Kanowit in the 1880s. Soon, the Brooke administration had offered peace with the Rajang and as a symbol of peace, a canon was given to the leader of the Rajang. Until now, the village across Kanowit River from the town is known as Kampung Bedil, from the name of the canon, which literally translated to bedil in the Rajang language. The Rajang still live along Rajang River at Kampung Bedil. There are only about 300 of them left (Haslina Bujang, 2018). Most have migrated to bigger cities and towns like Kuching, Miri, Sibu and Bintulu for employment. Throughout the years, the Rajang has assimilated with other ethnic groups, especially the Malays and Iban through marriage. The assimilation also slowly eroded their own culture, both tangible and intangible cultures such as language, belief system, food and etc. Other factors that also contribute to the erosion of the Rajang's culture include new religion, modernisation and urbanisation that gradually change their belief system and perspectives in life.

There have been studies on the Rajang cultures and language (Nor Hisham Osman, 1991; Yasir Abdul Rahman, 1987; Clayre, 1971; Edwards \& Stevens, 1971). However, there are no studies on the architecture of the Rajang. Just like other aspects of the Rajang's culture, vernacular housing is undergoing transition from traditional to modern, which contributes to the loss of the original traditional typology. Sooner or later the traditional vernacular architecture will disappear, which has happened to their once communal tall house. Therefore, this paper examines the evolution of the Rajang vernacular housing typology. The objective of this paper is to identify typology evolution and characteristics of the Rajang's dwelling.

\section{Literature Review}

\section{The concept of typology in architecture}

The word type has been derived from the Greek word 'Typos' which means 'impression'. According to Moneo (1978) in architecture, type means "a concept which describes a group of objects characterized by the same formal structure" (1978: 23). Typology in architecture is a comparative study of distinctive characteristics and elements of physical built environment features such as building types (Guney, 2007). Shi \& Wei (2017) defined it as the identifying commonness extracted from a group or classification of buildings. Ayildiz et al. (2017) also employed the concept of classification but included another elements as listing method to define building type, while Moneo (1978) used the terms grouping objects by certain inherent similarities through similar form properties, a space or combinations of both. The main aim of a typology study is to identify the conceptual basis by which buildings can be described and categorized into types used either as a basis for analysing buildings or as a basis for designing buildings (Amole, 2007). The development of typology study has been developed from the Renaissance period until now. However, throughout the era, the interpretation and meaning of typology has changed throughout three main eras - the Renaissance, modernism and neo-rationalist perspectives (Syahidah Amni Mohamed et al., 2017; Guney 2007). During the Renaissance era, the proponent of the Rationalist theory like 
Quincy regarded type as the fundamental principle of architecture, which cannot be further reduced (Amole 2007) and perceived as metaphorical imitation of nature (Im \& Han, 2015). During this period type can be symbolised by model, matrix, imprint, mould and figure in relief (Guney, 2007). Model is a set of standards while types differentiate architectural elements from one to another, which is conceptually based on origin, transformation and invention (Syahidah Amni Mohamed et al., 2017; Guney 2007).

Origin refers to essence of things that dictate the general form, structure and character of a building, which is a reflection of use, need, custom and creates character to the building. Invention, on the other hand is associated with the creative imitation of nature by taking into consideration local context, history and cultural needs, to transform elements into tangible artefacts through the syntheses of construction and developing spatial programming of the formal, functional and ecological principles as original and imaginative synthesis (Guney, 2007; Amole, 2007). Local context can be in the form of cultural imprint as a spatial reaction to climate and place, where material properties, airflow, energy and space are the main architectural devices (Passe, 2007). Transformation is the ability to reconstruct and link to historical past and architectural style (Guney, 2017) with the possibility to trace and explain the common generic sources (Amole 2007). Quincy defined typology as an abstract, basic, generic, indivisible principle of form as a useful analytical approach that can reveal the generic characteristics of the 'type' (Amole, 2007).

Im \& Han (2015) discussed the changes in relation to historical transformation of types and typology concepts by examining three developing stages based on methodological interpretation - type as a fundamental principle of architecture; type as manual for architecture; and type as production tool for architecture (Refer to Table 1). Type as fundamental principal of architecture is similar to the above discussion on how types was introduced and interpreted during the Renaissance period. The other two discussion whereby type is considered as manual and production tool for architecture is similar to Guney (2007) discussion on how the modernist theory interpreted types.

The modernist period was influenced by Durand interpretation of types, employing comparative taxonomy, whereby classification was done due to likeness and kinds (Guney, 2007). Durand also used descriptive geometry to classify buildings, which result to the development of the Modernist idea of prototype (Guney, 2007). Type as a production tool for a new norm was the new interpretation of Gropius who founded Bauhaus (Im \& Han, 2015) which marked the starting point of the Modernist movement, an era lasting for more than 30 years. Modernism swept the world for the standardised International style, hence, the focus on types as standardisation and emphasis on mass production of building through the prototypes without taking into account socio-culture, history and regional variation. The Modernist proponents believe in searching for purist, using ratio and science but leaving out the emotion and meaning when planning or analysing building and space.

\section{Table 1 Historical Transformation of Type and Typology Concepts}

\begin{tabular}{|c|c|c|}
\hline $\begin{array}{l}\text { Typology as a } \\
\text { fundamental principle of } \\
\text { architecture }\end{array}$ & $\begin{array}{l}\text { Typology as a manual for } \\
\text { making architecture }\end{array}$ & $\begin{array}{l}\text { Typology as a production } \\
\text { tool for a new norm }\end{array}$ \\
\hline $\begin{array}{c}\text { Quatremere de Quincy } \\
\text { - } \quad \text { Typology as a } \\
\text { principle of }\end{array}$ & $\begin{array}{ll}\text { J. N. L. Durand } \\
\text { • } & \text { Typology as a } \\
& \text { manual for creation } \\
& \text { based on a }\end{array}$ & $\begin{array}{l}\text { Walter Gropius } \\
\bullet \quad \text { Typology as an } \\
\text { obstacle to creating } \\
\text { new architecture }\end{array}$ \\
\hline
\end{tabular}


creation and rule

for "model"

- Type as

fundamental principle inherent to forms

- Model as a complete icon, Type as model's metaphorical imitation

Source: Im \& Han (2015:444)

\section{classification}

system

- $\quad$ Type as architectural elements

- Represented a series of types for composition Systematic combination of elements

In contrast to the Modernist perspective of types, the Neo-rationalist interpreted types by bringing back the continuity of form and history as an integral part of type's analyses (Guney, 2007). In architecture and urban design, the new proponents of typology studies regarded the relationship between building and space as concrete and specific, in contrast with the modernist proponents who considered it as merely abstract and generic. The analyses expanded further and tied up to morphological studies to understand architecture, by analysing the macro and micro development at various levels of the cities, from the city, district, streets and houses. Under the Neo-rationalist perspectives, there are three main school of thoughts - Italian, French and English approaches.

The Italian school were initiated by Muratori's method, known as the "Typological method" that distinguished between four scale levels - building, district, city and territory, whereby detail and complexity of the type change according to level (Cataldi et al., 2002). Within each scale, there are four aspects - elements of design; internal structure; relation between form and use and the formal aspect or materialization. Muratori's definition of 'type' is a construct of conventions and norms that exist in a certain region or town and that evolved over time on the basis of experience (Guney, 2007). Muratori believes that the urban form can only be understood in its historical dimension because it emerges from a succession of reactions and processes of growth with an emphasis on local and time specific thorough the identification of an 'archetype', by trying to reconstruct the lines of development from this archetype to later types (Cataldi et al., 2002; Guney, 2007). The French school approaches differ from the Italian, based on grounded theory, whereby one should not have any biasness and prior judgement during the process of urban analysis, a method used by many anthropologist and based on the ideas of Lynch, Cullen and Unwin. The French methods employ other disciplines as well to understand the urban form in relation to its end-users and functionality, such as sociologist, environmental and cognitive psychology (Guney, 2007). The English or Birmingham school, based on the works of Conzen and his colleagues uses a geographical approach in understanding urban form, in terms of ground use and functions and to spatial planning (Guney, 2007). Conzen works form the parcels and the ground plan rather than from buildings like the Italian and French schools. The approach tends more towards classical natural science: more from a distance and abstract trying to describe and analyse the spatial aspects of an urban form scientifically.

Typology in the context of this paper refers to the Renaissance rationalist theory, using Durand's interpretation of types. The typological study involves typological analysis involving categorizing the buildings within the same class on the basis of their differences. The study of building typology is more related to similar functions but of 
different form. Form can be with regards to roof, site location, façade, building materials, ornaments, detailing, spatial programming and etc.

Knowledge and understanding of type and typology is important to aid planning and policy-making to ensure the continuation of the local physical image of a region and shared memory of history, thus promoting regional characteristic (Shi \& Wei, 2017). Typology study is an elementary principle of architecture that can provide understanding to the meaning in architecture, enhancing understanding of architecture within its historical and socio-cultural contexts, through the identification of basic types (Syahidah Amni Mohamed et al., 2017). Typology study is also important to generate reasoning and knowledge in intellectual history, for architectural discourse (Guney, 2007). Amole (2007) highlighted the problems of studying architecture as in understanding, describing and classifying buildings and emphasising that the ability to differentiate differences in building of the same function is important because buildings constitute points of historical reference. Furthermore, building analysis also allows us to clearly identify and recognize the regional and cultural influences in the design of buildings (Amole, 2007).

\section{Vernacular housing}

Vernacular housing is a house that is built not based on the design of a formal architect, sometime it is also referred as "architecture without architect", a phrase coined by Bernard Rudofsky's (Hourigan, 2015). Salgin et al. (2017) defined vernacular architecture in relation to the building adaptation to culture, lifestyle, physical and climatic conditions, where a community resides, often establishing a harmonious relationship between climate, architecture and people. According to Hourigan (2015) vernacular in architecture used to be linked with terminologies like primitive, traditional, folk, "ordinary" or "everyday" that denoted as "non pedigreed" and lack novelty architecture in contrast to monumental buildings. However, in the West the interest in vernacular architecture started when William Morris started the Arts and Craft movement and return to artisanal values in the built environment as a way to fight the monotonous, monstrous effects of architectural design of the Industrial Revolution era. Morris believed that vernacular architecture had been evolved and perfected throughout times and the knowledge was passed down from generation to generation. However, vernacular architecture is not static and evolves through times by adapting and transforming itself to new functions and needs (Hourigan, 2015).

\section{Borneo Vernacular Architecture}

Vernacular architecture in Borneo is mainly represented by traditional dwellings. The traditional dwellings are distinct due to the existence of two categories - communal and individual. Communal dwellings are common for the indigenous groups who lived in the highlands, mainly of the Dayak groups, such as the Iban, Orang Ulu and Bidayuh of Sarawak and Kalimantan, and the Rungus and Murut of Sabah. In the coastal areas are the Malays and Melanau who reside in individual dwellings, which are common features in Sarawak, Brunei, Sabah and Kalimantan, mainly along rivers or on rivers (known in Brunei as Kampung Air). Traditionally, the Melanau lived in communal dwelling, known as the Tall House. Later, they assimilated with the Malays and as a result, their dwelling styles had changed to individual dwellings. Both communal and individual dwellings are built from building materials available locally, mainly from hard-wood and non-timber forest products, such as bamboo, palms and etc. The dwellings are also on stilts mainly to cater for micro climate needs, such as to allow cross ventilation on 
the lower level and to protect the residents from wild animals, enemies and flood. Victoria et al. (2017) shows that the traditional Iban longhouse in Sarawak displays a good bioclimatic building design in terms of adaptability to the tropical climate by maximising ventilation and natural lighting. Ornaments and spaces are mainly to meet socio-economic and socio-cultural needs, such as the common space for social and religious gathering, drying area for processing of agricultural products. Ornaments like gable horn of the Bajau traditional houses in Sabah has various function, such as, to stabilise the roof during monsoon season, sign of social status and to ward off evil spirits (Chen Voon Fee, 1998).

\section{Methodology}

\section{Study Area}

The study area is in Kampung Bedil, Kanowit. Kampung Bedil is divided into three parts - Bedil 1, Bedil 2 and Bedil 3. Bedil 1 and Bedil 2 can be accessed by road but Bedil 3 can only be accessed by river. Bedil 1 and 2 consist of individual dwellings, however Bedil 3 dwelling is of communal and resembling more of an Iban longhouse, due to many intermarriages between the Rajang and the Iban. There is a total of 24 houses left at Kampung Bedil, 15 houses at Bedil 1 and only 9 houses at Bedil 2. The study area is at Kampung Bedil 1 and Kampung Bedil 2 (Refer to Figure 2).

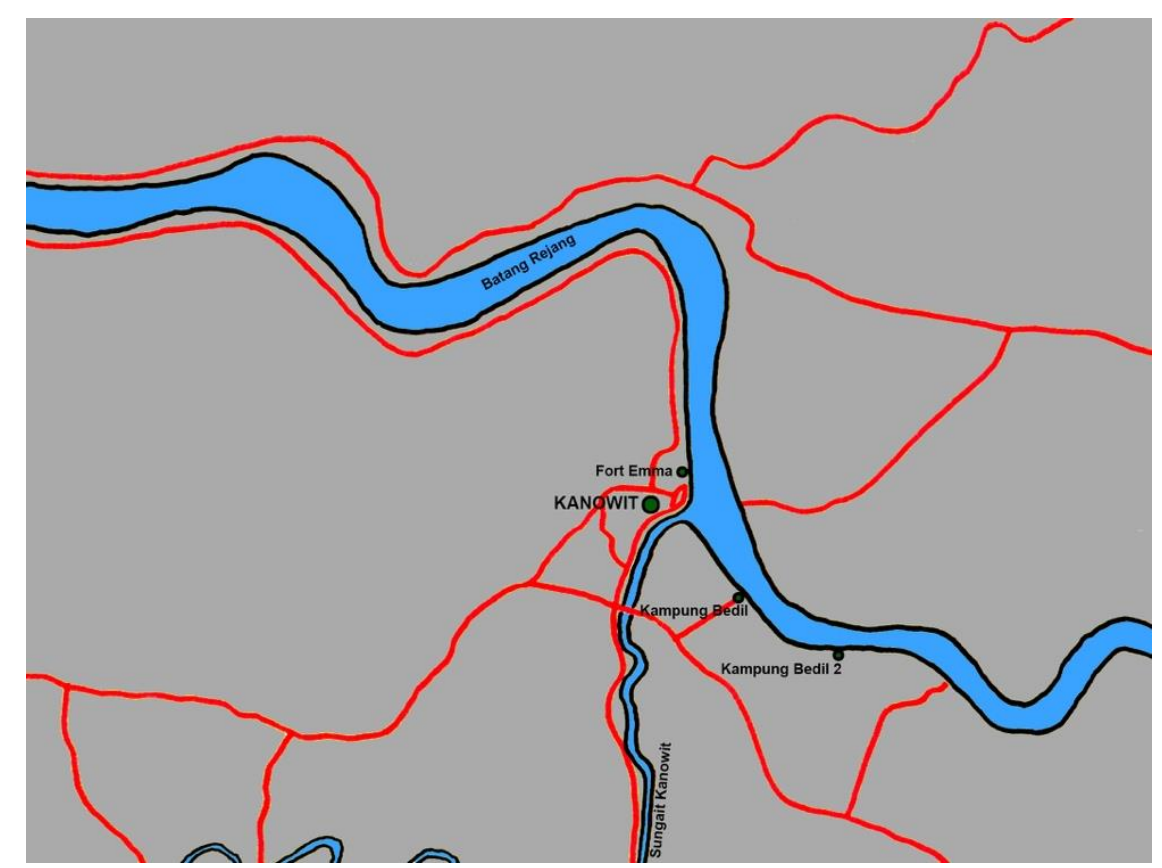

Figure 2: Map of Kampung Bedil in relation to Kanowit

Source: Author

\section{Methodology}

The research methods employed a qualitative approach. The first stage of the research includes in-depth interview with two community leaders in Kanowit - a Penghulu and a Ketua Kaum of the Rajang ethnic group. The two community leaders act as informant 
to link us with the rests of the villagers in Kampung Bedil 1 and 2. In-depth interview with the house owners are done, for those who are available.

A building survey is then conducted by taking a census of all the houses 24 houses at Bedil 1 and 2 to identify types of the vernacular house, site and spaces. Selected houses are documented more accurately, whereby, a measured drawing was done to document the dwellings based on their historical and distinct values. The building survey focused on building ownership, occupancy, building condition, architectural elements, building alterations and usage. The survey is essentially a documentation of the type of the buildings and spaces. Each building is photographed for further analyses. The main method used for this research is visual and historical analyses. Visual Analysis is done by analysing plans and photographs of a building or a spatial area. Visual analysis examines various elements, such as; How does the space feel? Does the function of space work as intended? What is the spatial sequence? How does a person move from one space to another? How does it fit the site? What are the views from one place to another? How does the structure work? How does it work in the local climate? How does it work in the village? Historical analysis requires research into the historical circumstances surrounding the community and building. What ideas and circumstances was the building addressing?

Upon completing both visual and historical analyses, classification of the buildings and space is developed through an empirical process of induction and iteration. As the amount of material grows, preliminary theories can be derived (induction) from it. As the evidence mounts the theory can be refined (iteration). The process are done by identifying main characteristics in complex visual information. The steps of this process include: inventorisation, by describing or recording photographs, drawings and the objects to be typified in detail. When a fair number of objects have been observed or recorded the possibility arises to systemize them and to get a first idea of the criteria for a typology. The first cautious criteria can be used to make a first classification by regrouping the objects into families that comply with a number of criteria. The simplest way to do this is by starting with the clearest cases.

\section{Findings}

\section{Evolution of the Rajang's vernacular housing}

The most significant evolution of the Rajang vernacular housing is the transition from communal tall long house to individual house. According to the ex-Rajang Ketua Kaum (community leader), who is also the father of the current Rajang Ketua Kaum, the Rajang of Kampung Bedil used to live in a long house on stilt, opposite the river. The communal house used to house between 20 to 30 bilik (households). The existing village in Bedil used to be their orchard and farming areas and they eventually moved to the existing village and started to build individual houses due to two factors; nearer to the orchard and farm; and easier accessibility to Kanowit, the nearest urban centre from Kampung Bedil. Before the bridge was built to link Kanowit to Kampung Bedil, there was a ferry service linking them to Kanowit town. The Rajang have a close relationship with the Orang Ulu, such as the Punan and the Kayan probably due to language affinity. During our fieldwork, some of the workers in the farm were of Orang Ulu origin. The community of Bedil has a close relationship with the Melanau of Kampung Nangka and Banyok in Sibu, through family kinship. Just like the Melanau of Kampung Nangka and Banyok, their socio-economic activities are mainly paddy planting (swamp paddy), 
orchard farming and fishermen. The Rajang are also excellent boat builders because the rivers used to be their highway in the early years.

The traditional Melanau long house is built of belian timber, nibong and palm thatch roofs. The spacing inside the house is programmed in such a way that the middle part of the long house is a common public space, shared by the inhabitant, in contrast to other ethnic group in Sarawak that programmed their public areas on the front part of the house (Refer to Figure 3). Historically, the house is designed for security to protect the households from enemies and pirates (Sim, 2010; Bahauddin \& Awang Musadat, 2018).

The Rajang's housing is not only evolving from communal to individual type, the location of the housing also changes (Refer to 4). Figure 4 shows the movement from the longhouse to a new village across the river as early as the seventeenth century. Initially, the houses were built along the river bank, but due to soil erosion, the villagers moved further inland into their orchard. Soil erosion was claimed to be caused by the waves from the frequent trips of the express boats from Sibu to Kapit. Later, the houses started to disperse and formed Kampung Bedil 2 and 3.

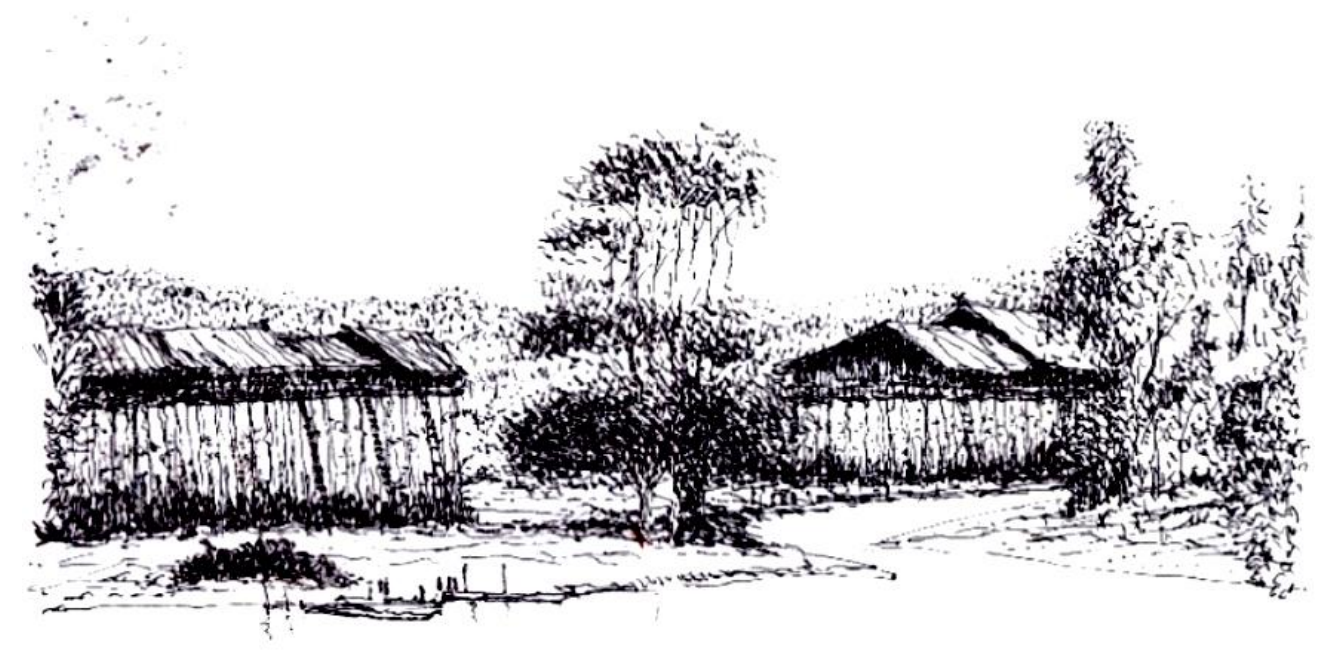

Figure 2: Illustration of the Rajang Long house

Source: Author

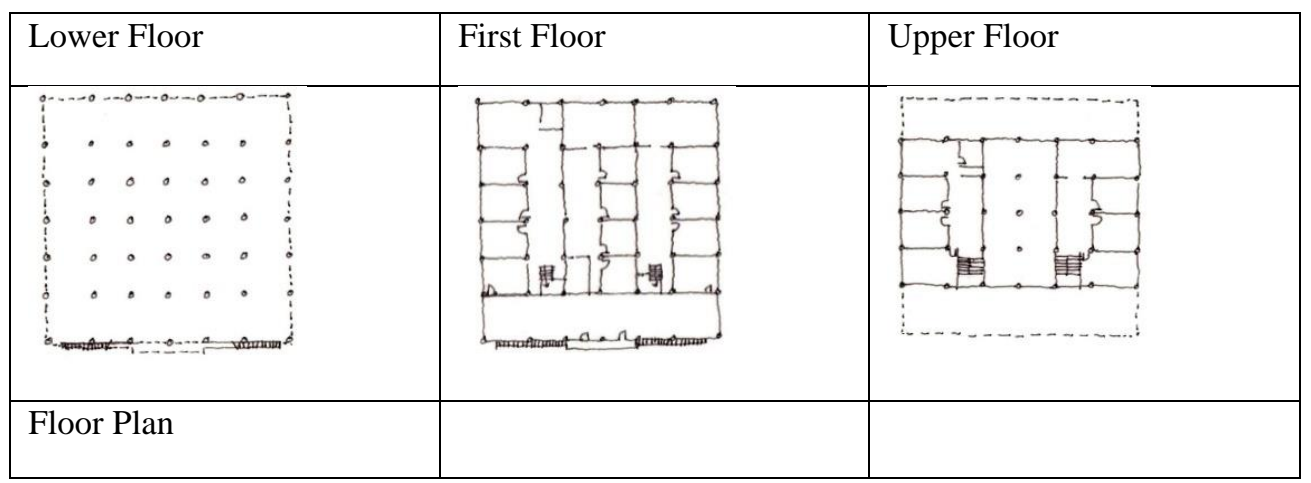




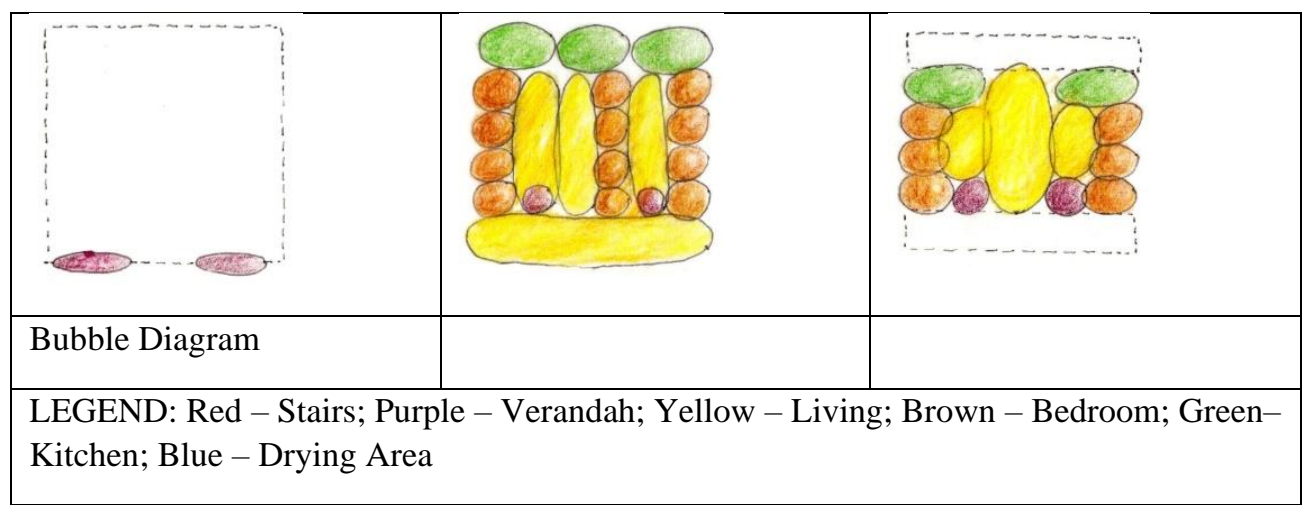

Figure 3: Floor Plan and Bubble Diagram Analyses of the Rajang Longhouse Source: Author

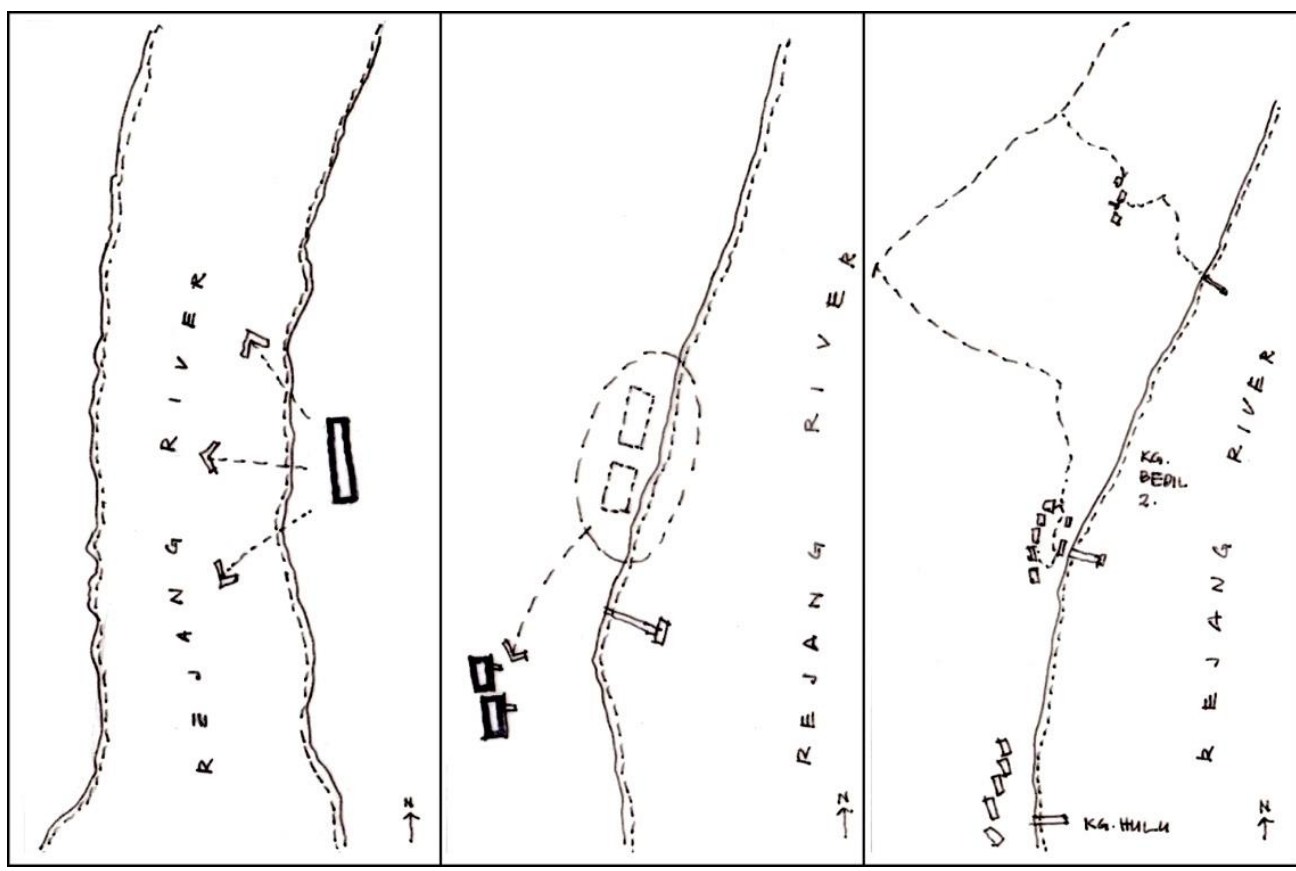

Across the river

River bank to Inland

Dispersal

Figure 4: Site location showing movement of the villages

Source: Author

The building survey shows that in terms of occupancy all are house owners, implying that there is no tenant. Most of the house are still vacant although, the occupants are mainly of the elderly group. Several owners of working group age between 30 to 50 years old visited their houses and orchards during weekends because they work in Kanowit or in nearby towns like Sibu or Bintulu. Many of the children of the household have also either moved elsewhere or to the new housing scheme at Kampung Muhibbah in Kanowit. Housing conditions are mainly fair and there are two abandoned houses in poor conditions because the owners have migrated to Kuching and seldom visit their houses. There are more houses in Bedil 1 than 2 because Bedil 1 is the original village and linked to the tarmac road. During our fieldwork, access to Bedil 2 was through a dirt 
road under construction. According to one of the respondents, when the tarmac road is completed, more will return to their houses because of better accessibility.

The houses are all on timber stilt. Although most of the house have original structures, most of the walls have been changed. Early and Intermediate typology are of vertical planks. The modern typology is mainly of horizontal timber planks. Several houses have changed to mixed of brick and horizontal timber planks. This is common when they have renovated the lower part of the house into rooms and living rooms. For those who cannot afford, many change to asbestos wall, of whom all of them are in Bedil 1.

\section{Table 2 Summary of Building Survey}

\begin{tabular}{|c|c|c|}
\hline Item & Kampung Bedil 1 & Kampung Bedil 2 \\
\hline Occupancy & 15 owners & 9 owners \\
\hline Status & 14 occupied, 1 vacant & 6 occupied, 3 vacant \\
\hline Condition & 2 excellent, 5 good, 8 fair & 3 good, 4 fair, 2 poor \\
\hline Structure & All on stilt & All on stilt \\
\hline Wall & $\begin{array}{l}6 \text { horizontal plank, } 3 \text { mixed, } \\
6 \text { asbestos }\end{array}$ & $\begin{array}{l}6 \text { horizontal plank, } 3 \text { vertical } \\
\text { plank }\end{array}$ \\
\hline Wall material & $\begin{array}{l}6 \text { timber, } 3 \text { mixed of timber } \\
\text { and brick, } 6 \text { asbestos }\end{array}$ & All timber \\
\hline Window & $\begin{array}{l}5 \text { casement, } 7 \text { louvered, } 2 \\
\text { sliding, } 1 \text { mix of sliding and } \\
\text { louvered }\end{array}$ & 3 casement, 6 louvered \\
\hline Window material & 5 timber, 10 glass & 3 timber, 6 glass \\
\hline Roof & 4 gable end, 8 pitch, 3 mixed & 4 pitch, 2 hip \\
\hline Roof material & All spandex (metal roof) & All spandex (metal roof) \\
\hline \multicolumn{3}{|l|}{ Other details: } \\
\hline Balustrade & 5 yes, 10 no & 5 yes, 4 no \\
\hline Verandah & 7 yes, 8 no & 5 yes, 4 no \\
\hline Fascia & All yes & All yes \\
\hline Roof finial & All no & All no \\
\hline Pediment & 6 yes, 9 no & All no \\
\hline Linkages & All no & 2 yes, 7 no \\
\hline Change of level & 1 yes, 14 no & 4 yes, 5 no \\
\hline
\end{tabular}

Source: Author

The traditional window is of timber casement. However, the building survey shows that most of the houses have changed their windows to glass louvered and some of the houses even changed to sliding window. Most of the roof are pitch. Other type includes gable end and hip roof. In Bedil 1, due to renovation, there are some mixed type, which cannot be clearly identified. All of the roof are made of metal, spandex type. The houses are very minimal and lack ornamentation. There are sign of balustrade elements, especially if the houses have verandah. All of the houses have simple fascia board with no ornaments, merely for functional reason. There is no sign of roof finial on the roof of all houses. There are only small proportion of houses with pediment, only at Bedil 1 . There are also small number of houses with linkages and change of level between the different functional spaces. The change in building materials to modern materials are due to scarcity and higher cost of timber. Change of level and linkages are typical characteristics of a Malay traditional houses. This shows that despite the evolution of the Rajang house from communal to individual house, they do not necessarily follows a 
typical Malay houses layout. The houses are mainly built for basic shelter needs and spaces are mainly influenced by socio-economic activities rather than ritual and cultural needs.

\section{Case study of three main typology}

From the building survey, three distinct types were identified and related to timeline that indicated evolution of the dwelling according to timeframe. The Rajang started to build the earliest typology, refer in this case study as "Early Typology" from the seventeenth century when they moved across the river from communal to individual dwelling. The second type - known as "Intermediate Type" was built during the nineteenth century while the "Modern Type" started after 1960s but this type established its main characteristics from 1980s onwards. All of the three types are located in Kampung Bedil 2 , the earliest typology is in a different cluster, further inland from the river, while the other two are just at the river bank (Refer to Figure 5).

In terms of spatial programming as shown by the bubble diagram and floor plan, the Early Typology shows that the house is not only meant for shelter but also for socioeconomic activies as indicated by the drying open space areas, which resembles the Iban's longhouse tanju. This space is mainly to dry agricultural products especially paddy. The Rajang plant swamp paddy, but the practise is getting less now. In contrast, the other two houses, do not have any open drying up areas. The Early Typology is smaller and more ergonomic in terms of scale. The dimensions are designed and planned based on human scale, using the depa, the dimension between the tips of the fingers of the horizontally out-stretch arms (Husli, 2011). Whereas, the other two houses used either the British Imperial or US metric measurement. This can be seen clearly from the dimension, volume and height of the buildings. Although the Early Typology is smaller but the functional spaces are more varied and complex, with the verandah, living area, bedroom, kitchen, drying space and a toilet. The simplest functionalist space arrangement is the Intermediate Typology, whereby, there is no change of level and the spaces are all in one rectagular floor plan, without a verandah and drying area. The Modern Typology has the biggest spacing with a link from the main living to the kitchen and a huge verandah (Refer to Figure 5). One of the reasons for the two latest typologies not to include socio-economic space is because they have a small hut, locally known as dango in the orchard for temporary shelter and agricultural storage. Furthermore, the owner of the Modern Typology is working as civil servant and is only doing farming activities during his leisure time. The first two earlier typologies are of vertical horizontal timber plank wall, in contrast, the Modern Typology comprises horizontal timber plank painted in green.

The structures of the building are post and beam with traditional timber stump. The Modern Typology are taller and the structures of the house are strengthened by timber bracing (Refer to Figure 6). The front elevations indicate that all of the doors are located on the right side, as one approaches the house and the windows on the left side and along the left and right elevations of the houses. The Early Typology has a tall double casement timber windows of about $1.8 \times 0.8$ metres, with balustrades on the bottom half, extended from the floor above, which can be found on the front, left and right elevations allowing the flowing of natural air ventilation throughout the house. The Intermediate Typology has smaller single casement timber windows, while the Modern Typology has glass louvered windows. Profiling of the roof seems to be similar from the front elevations, a typical pitch roof. However, as one studies the roof plan, the Early 
Typology is of pitch roof with a gable end to the back, which is similar to "Gajah Menyusu" roof style, but at the back part of the house, instead of in front the house. The Modern Typology roof plan is similar to "Rumah Tiang Duabelas", with parallel pitch room and a valley in between.

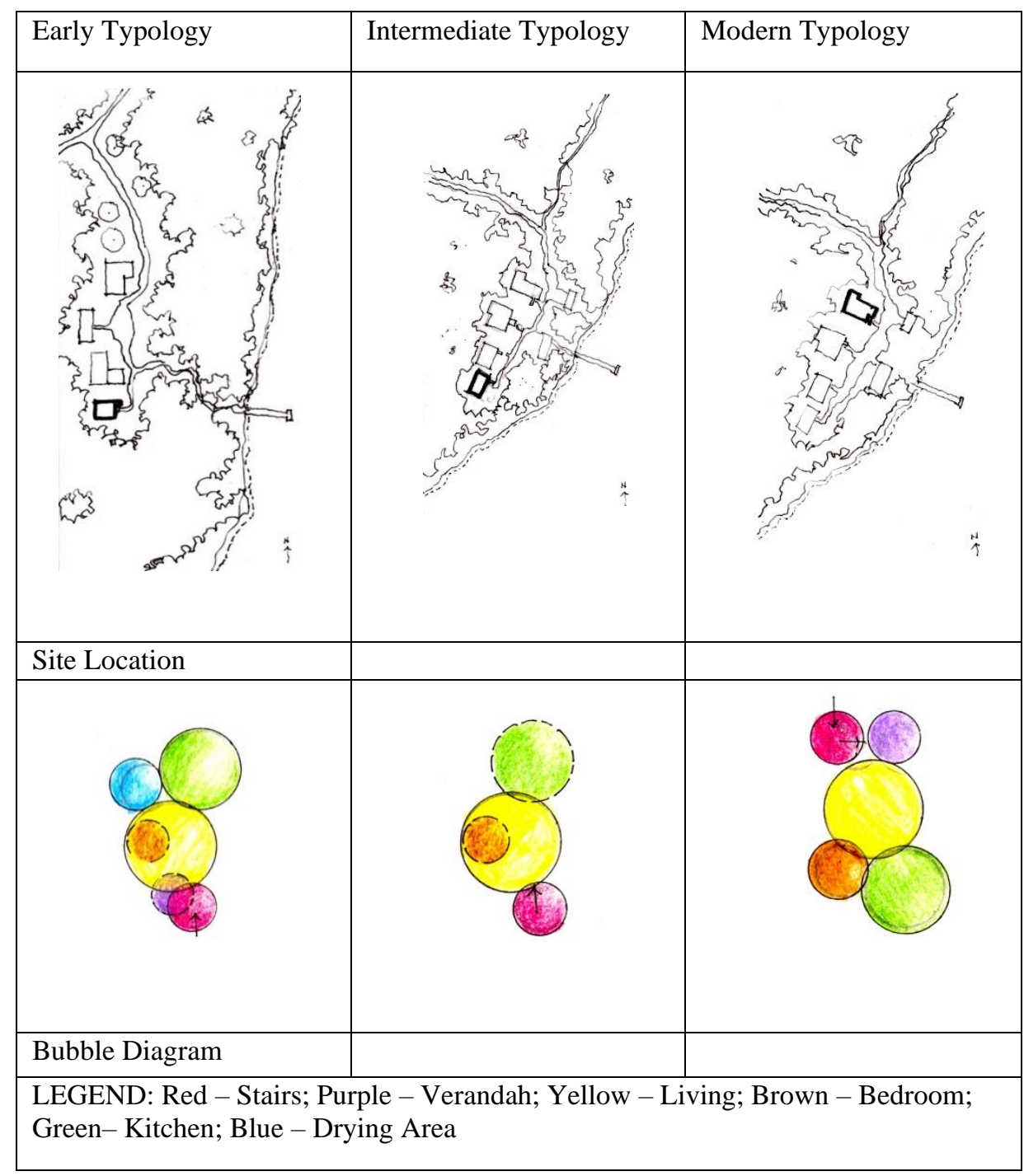




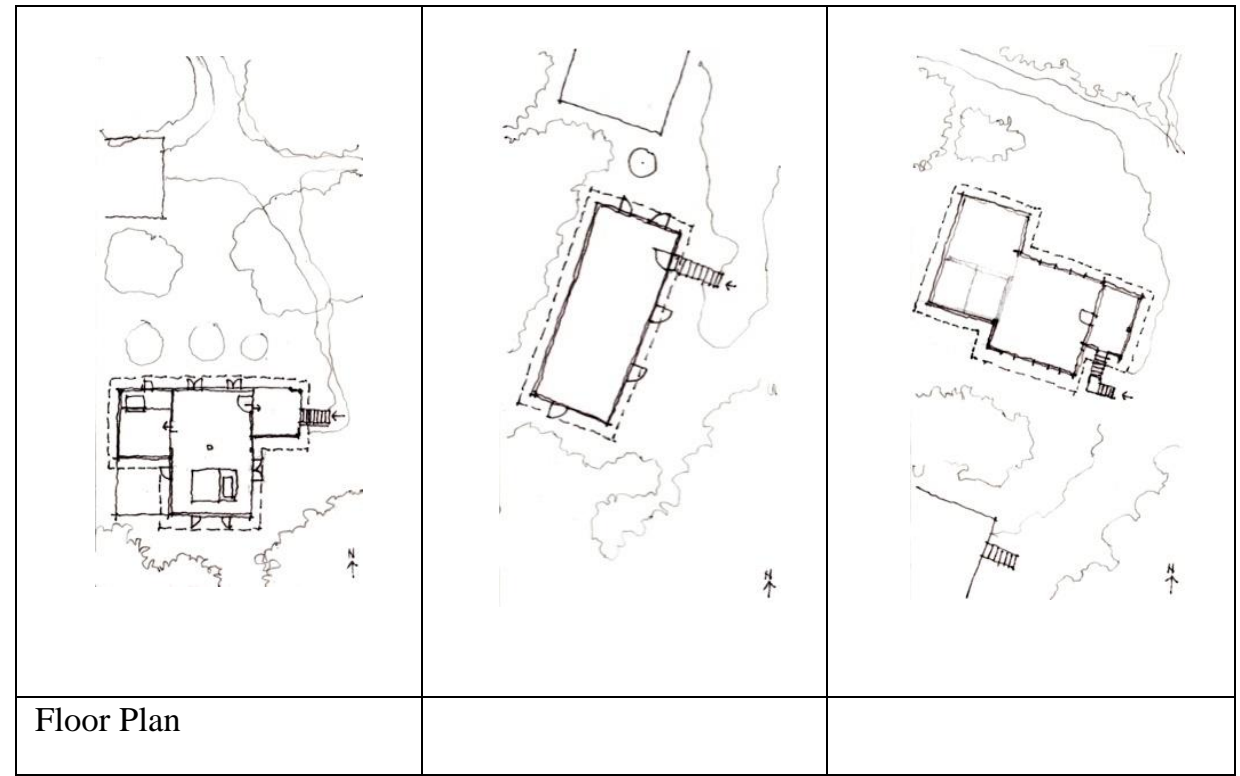

Figure 5: Site location, Bubble Diagram and Floor Plan of the three typologies

Source: Author

Early Typology




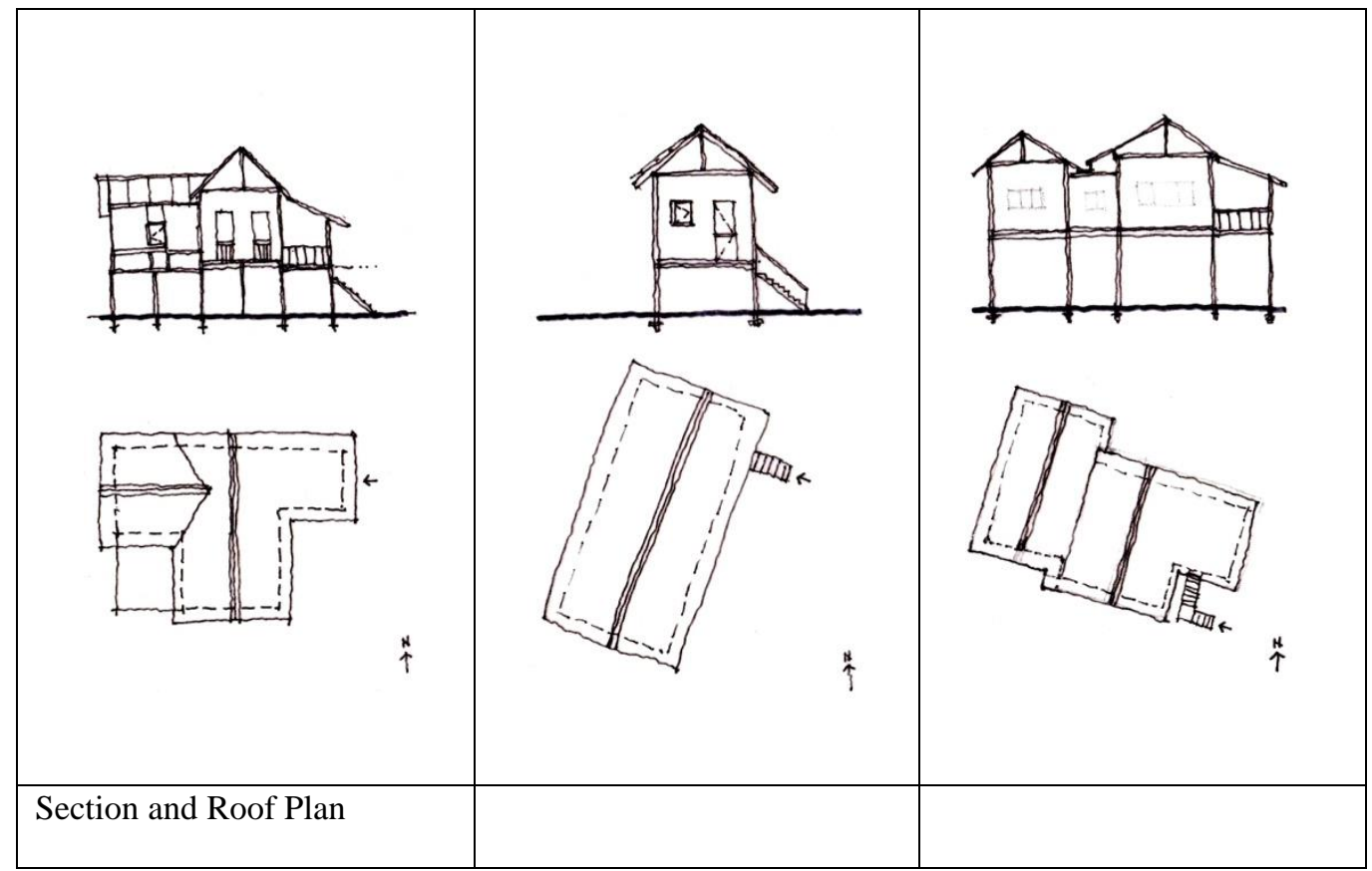

Figure 6: Elevations, Sections and Roof Plan of the three typologies Source: Author

\begin{tabular}{|l|l|l|l|l|}
\hline Early Typology & Intermediate Typology & Modern Typology \\
\hline & & & & \\
\hline
\end{tabular}




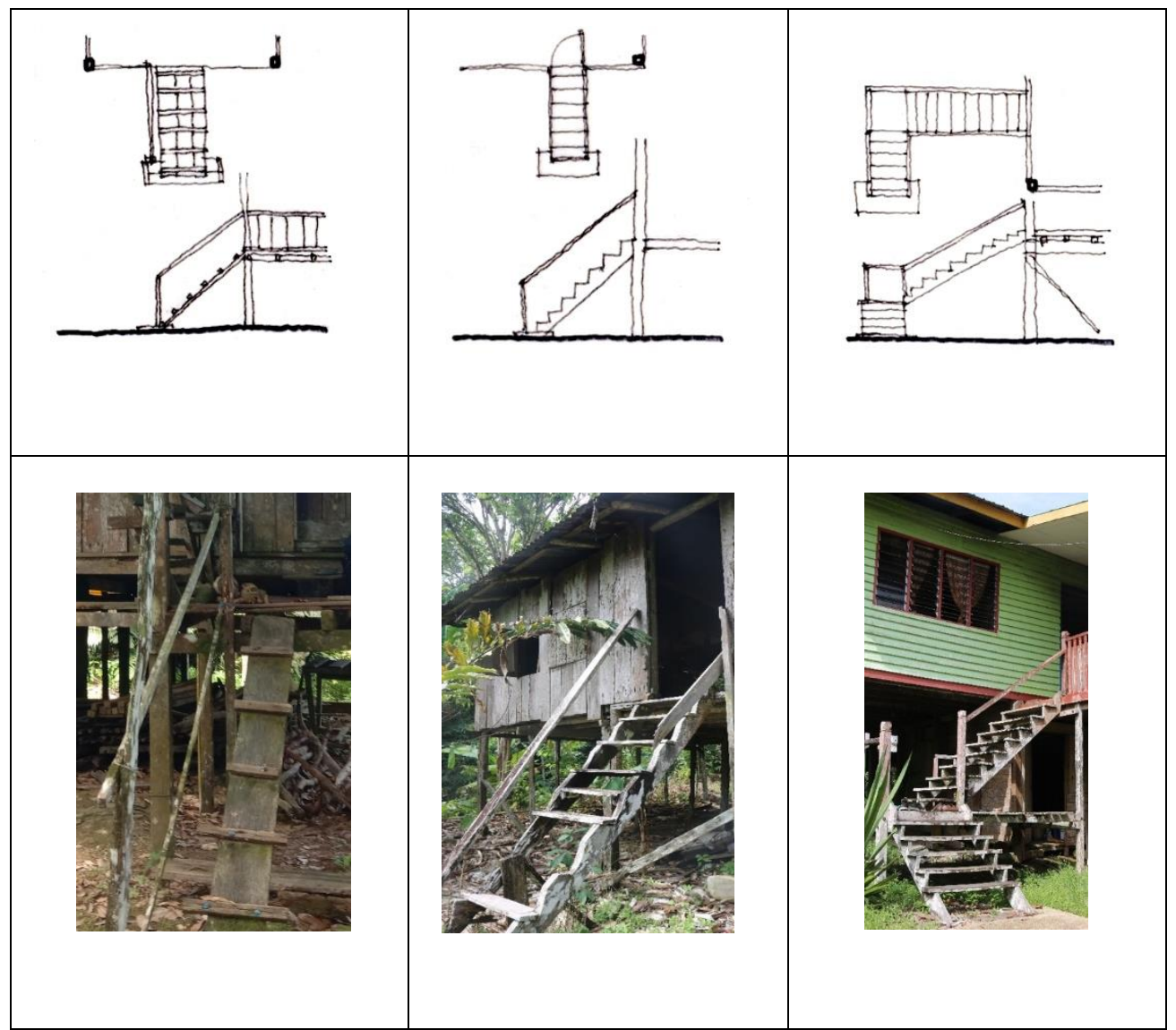

Figure 7: Doors, Windows and Staircase

Source: Author

The most unique elements of the Early Typology is the staircase, which is made from a timber plank and attached onto it are timber batons that act as risers entering towards a small verandah. The Intermediate Typology has a staircase going up straight to the living area. The Modern Typology has a staircase with a landing in between, this is also typical of the traditional Malay house at Kampung Hilir in Kanowit. All of the staircases have railing only on one side.

\section{Conclusion and Discussion}

The Rajang dwelling has evolved from the tall and long communal house to individual houses. There was suggestion that the evolution from communal to individual houses was influenced by the Malay. However, further investigation of the housing typology shows that despite the evolution from communal to individual houses, they do not necessarily follow a typical Malay house layout. The houses are mainly built for basic shelter needs and spaces are mainly influenced by socio-economic activities than sociocultural needs. Case study of the three typologies - Early Typology, Intermediate Typology and Modern Typology are from different timeline, from the seventeenth century onwards, indicating the evolution of the dwellings, from a smaller house with socio-economic function to a slightly larger house with simplified space function not related to socio-economic activities due to changes in owner's profession. The evolution 
in terms of functional space programming, size and building materials also indicate that the vernacular dwellings are not static but dynamic in response to socio-economic, socio-cultural and new technology and building materials.

\section{Acknowledgement}

We would like to thank UCTS for funding this research under UCTS Research Grant with the title of "Identifying Typologies of Vernacular Malay Dwellings in Central Sarawak for Heritage and Cultural Sustainability". We would also like to thank Student Research Assistants; Anas, Ahza, Othmancheng, Kelvin, Mei and Anton for assisting in the field for data collection.

\section{References}

Amole, D. (2007). Typological analyses of students' residences. ArchnetIJAR,International Journal of Architectural Research, Vol 1, Issue 3, 76-87.

Ayyildiz, S., Erturk, F., Durak, S. \& Dulger, A. (2017). Importance of typological analysis in architecture for cultural continuity: An example from Kocaeli (Turkey). WMCAUS, IOP Conf. Series: Materials Science and Engineering 245, 072033, 1-15.

Bahauddin, A. \& Awg Musadat, D.M.S., (2017). The traditional architecture of the Melanau Tall Longhouse, Mukah, Sarawak. ICLK, SHS Web of Conferences 45, $1-7,01002$.

Boneo Post Online (2015). Tracing the origin of the name Kanowit. Retrieved on 1 December 2019. Retrieved from https://www.theborneopost.com/

Borneo Post Online (2015). Historical Fort Emma in danger of collapsing. Retrieved on 1 December 2019. Retrieved from https://www.theborneopost.com/

Cataldi, G., Maffei, G. L. \& Vaccaro, P. (2002). Saverio Muratari and the Italian School of Planning Typology. Urban Morphology, 6(1), 3-14.

Chen Voon Fee (1998). The encyclopaedia of Malaysia: Architecture, New York: Archipelago Press

Clayre. I. (1970). The spelling of Melanau (nee Milano). The Sarawak Museum Journal, $18,330-352$

Department of Statistics Malaysia (2010). Population Distribution and Basic Demographic Characteristics. Retrieved on 1 December 2019. Retrieved from https://www.dosm.gov.my/

Edwards, L. \& Stevens, P.W. (1971). Short histories of the Lawas and Kanowit Districts. Kuching, Borneo Literature Bureau.

Guney, Y.I. (2007). Type and typology in architectural discourse. BAUFBE Dergisi, Cilt, 9, Balikesir. Retrieved on 1 December 2019. Retrieved from http://fbe.balikesir.edu.tr/dergi/20071/BAUFBE2007-1-1.pdf

Haslina Bujang (2018). Etnik Kanowit, Sarawak, Borneo. The Patriots. Retrieved on 1 December 2019. Retrieved from https://www.thepatriots.asia/etnik-kanowitsarawak-borneo/

Hourigan, N. (2015). Confronting classifications - when and what is vernacular architecture? Civil Engineering and Architecture 3(1), 22-30.

Husli, Y. (2011). The assessment of measurement application for timber traditional Malay house. University Malaysia Pahang thesis. Retrieved on 5 December 2019. 
Im, J. \& Han, J. (2015). Typological Design Strategy of FOA's Architecture, Journal of Asian Architecture and Building Engineering, 14:2, 443-449. Retrieved on 30 November 2019. Retrieved from https://www.tandfonline.com/loi/tabe20

Kaboy, T. (1965). The Murder of Steele and Fox, The Sarawak Gazzette. June 30 1965, 178-180. Retrieved on 1 December 2019. Retrieved from https://www.pustakasarawak.com/gazette/gazette_uploaded/1404720846.pdf

Moneo, R. (1978). On typology. Oppositions, A Journal for Ideas and Criticisms in Architecture, Summer, 13, 23-45.

Nor Hisham Osman (1991). Pemeliharaan dan penyisihan bahasa: Kajian kes terhadap komuniti minoriti Rajang-Tanjong. Universiti Malaya thesis. Universiti Malaya. Retrieved on 1 December 2019.

Passe, U. (2007). Sustainable building typologies: Free flow open space as a climate technology. The International Journal of Environmental, Cultural, Economic and Social Sustainability, Vol 3. Retrieved on 30 November 2019. Retrieved from http://www.Sustainability-Journal.com

PeKhabar (2015). Serangan ke atas kubu British di Kanowit, Sarawak. Retrieved on 1 December 2019.Retrieved from https://pekhabar.com/serangan-ke-atas-kububritish-di-kanowit-sarawak/

Salgie, B., Bayram, O. F., Akgun, A. \& Agyekum, K. (2017). Sustainable features of Vernacular Architecture; Housing of Eastern Black sea region as a case study. Arts, 6, 11, 1-14. Retrieved on 2 November 2019. Retrieved from www.mdpi.org/journal/arts.

Shahidah Amni Mohamed, Nor Zalina Harun \& Anis Abdullah (2017). Typomorphology as an approach for the conservation of the Early Malay Town. Asian Journal of Environment, Vol 1, Issue 2, 143-154.

Shi, W. \& Wei, S. (2017). Analyses based on design method of architectural typology in Modern Interpretation - "Earth Building Commune" as an example. 2nd International Conference on Education, Sports, Arts and Management Engineering (ICESAME 2017), Advances in Social Science, Education and Humanities Research, Volume 123

Sim, S. (2010). Redefining the Vernacular in the Hybrid Architecture of Malaysia. Master of Architecture, Victoria University of Wellington. Retrieved on 28 November 2019.

Victoria, J., Mahayuddin, S. A., Wan Zaharuddin, W. A. Z, Harun, S.N. \& Ismail, B. (2017). Bioclimatic design approach in Dayak traditional longhouse, International High Performance Built Environment Conference - A Sustainable Built Environment Conference 2016 Series (SBE16), iHBE 2016, Procedia Engineering, 180 (2017), 562-570.

Yasir Abdul Rahman. (1987). Melanau Mukah (Satu Kajian Budaya). Kuala Lumpur, Malaysia: Dewan Bahasa dan Pustaka. 